\title{
RELAÇÃO ENTRE OBESIDADE E DOENÇA PERIODONTAL
}

Sávio BRANDELERO JUNIOR; Sandra Lucinei BALBO.

A placa bacteriana é o agente etiológico primário das doenças periodontais. Entretanto, sabe-se que os microorganismos por si só não são capazes de desenvolvê-las, sendo necessário a interação com fatores de risco do hospedeiro. A doença periodontal só ocorre quando a agressão microbiana e a resposta do hospedeiro são alteradas para um ou outro lado. A obesidade é um fator de risco inerente ao hospedeiro que aumenta a probabilidade de ocorrência da doença periodontal. Sugere-se que a resistência à insulina sirva como mediador na relação entre obesidade e doença periodontal, e que a severidade da doença aumente proporcionalmente a elevação da resistência à insulina. $O$ alto índice de massa corporal afeta a imunidade do hospedeiro devido à diminuição do fluxo sanguíneo, pois causa hiperplasia e hipertrofia dos vasos periodontais. O inibidor do ativador de plasminogênio-1 induz a aglutinação de sangue podendo diminuir o fluxo sanguíneo no periodonto de obesos provocando a periodontite. Além disso, o tecido adiposo secreta citocinas pró-inflamatórias que promovem um processo inflamatório crônico das estruturas periodontais. Embora estudos mostrem evidências quanto à predisposição do obeso à doença periodontal os mecanismos envolvidos neste processo permanecem ainda desconhecidos. 